\title{
Malacological Study of the Momuna (Iguape, Brazil) Shell-middens and their Paleoenvironmental Significance
}

\author{
Estudo Malacológico de Sambaquis de Momuna (Iguape - SP) \\ e o seu Significado Paleoambiental
}

\author{
Roberto Barbosa Rodrigues' (roberbr.exm@hotmail.com), Kenitiro Suguio² (gsaigc@usp.br), \\ Alethéa Ernandes Martins Sallun³ (alethea@igeologico.sp.gov.br),

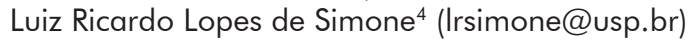 \\ 'Centro de Pós-graduação Pesquisa e Extensão - UnG \\ Praça Tereza Cristina 1, CEP 07023-070, Guarulhos, SP, BR \\ ${ }^{2}$ Departamento de Geologia Sedimentar e Ambiental - Instituto de Geociências - USP, São Paulo, SP, BR \\ ${ }^{3}$ Instituto Geológico - Secretaria do Meio Ambiente do Estado de São Paulo, São Paulo, SP, BR \\ ${ }^{4}$ Museu de Zoologia - USP, São Paulo, SP, BR
}

Received 20 October 2010; accepted 09 February 2011

\begin{abstract}
The shell-middens present in the Iguape (São Paulo State) coastal plain are situated at different distances from the present shoreline. In general, the more external shell-middens, which show a dominance of Anomalocardia brasiliana shells, give younger ages than the more internal shell-middens, which correspond to the Holocene most important lagoon expansion occurred between 5 and 6 ky B.P., and are commonly composed of Crassostrea brasiliana shells. Moreover, it was observed that the $\delta^{13} \mathrm{C}_{(\mathrm{PDB})}$ ratios of the shells change according to the geographic location of the shell-middens, as a function of RSL (Relative Sea-Level) fluctuations with time. In this paper, the malacofauna of the shell-middens of the Momuna 1 and 2, both located at the homonymous village (Iguape, São Paulo State, Brazil), on the Cananeia Formation (120 ky B.P.), was studied.
\end{abstract}

Keywords: Shell-middens; Lagoon expansion; Relative Sea-Level (RSL).

\section{RESUMO}

Na planície costeira de Iguape (SP) ocorrem sambaquis, que se acham situados a diferentes distâncias da atual linha de costa. Em geral, os sambaquis mais externos apresentam idades mais novas com predominância de conchas de Anomalocardia brasiliana, enquanto que os sambaquis mais internos, correspondentes à fase de maior expansão lagunar holocênica, entre 5 a 6 ka B.P., comumente apresentam a Crassostrea brasiliana. Além disso, têm sido verificado que as razões $\delta^{13} \mathrm{C}_{(\mathrm{PDB})}$ das conchas variam segundo as posições geográficas dos sambaquis, em função das flutuações do NRM (nível relativo do mar) com o tempo. Neste trabalho foram estudadas malacofaunas de sambaquis de Momuna 1 e 2, situados na localidade homônima (Iguape, SP), sobre terraços pleistocênicos da Formação Cananeia (120 ka B.P.).

Palavras-chave: Sambaquis; Expansão lagunar; Nível relativo do mar (NRM). 


\section{INTRODUCTION}

The Cananeia-Iguape coastal plain is located at the southeastern region of Brazil (São Paulo State) and, due to the geographical circumstances dictated by its geologic evolution, it is a place of easy access when travelling from the countryside to the coast of this state (Neves and Okumura, 2005). Approximately $85 \%$ of its total area integrates the Jureia-Itatins Ecological Station, which is characterized by hillside and strandplain forests, as well as other relatively well-preserved ecosystems, such as mangrove swamps.

Geomorphologically, the Cananeia-Iguape coastal plain is characterized by a flat lowland, which average elevation is $10 \mathrm{~m}$ above the present sea-level, and where some hills, constituted by crystalline rocks and with elevation much more higher than the average elevation, sparsely occur.

The coastal plain areas with higher elevations (5 to $10 \mathrm{~m}$ ) are constituted by the deposits of the Cananeia Formation with approximately 120 ky B.P., which were formed during the homonymous transgressive episode. The coastal plain areas with lower elevations (less than $5 \mathrm{~m}$ ) are formed by the deposits of the Ilha Comprida Formation, with an age ranging from 5 to 6 ky B.P., corresponding to the Santos transgressive episode, which encroached the valleys carved in the Cananeia Formation during the LGM (Last Glacial Maximum). An approximately 2 to $3 \mathrm{~m}$ high sea-cliff is quite visible from the Momuna village, where Holocene Ilha Comprida Formation was abutted against Pleistocene deposits of the Cananeia Formation.

Presently, its outer portion is drained by estuarine channels subject to microtidal regime (varying less than $2 \mathrm{~m}$ ). Several coastal shell-middens occur in this area, usually on Pleistocene substrates (Martin, Suguio, Flexor, 1984; Suguio, Martin, Flexor, 1992). Most of these shellmiddens are related to the paleolagoon expansion (Flexor, Martin, Suguio, 1979) that occurred worldwide during the hypsithermal period (Suguio, 2001) and seems to have influenced the studied area.

Although there are several papers on the coastal paleoenvironments, the literature on the malacology of shell-middens, which are important pre-historic sites in Brazil known at least since XIX century (Löfgren, 1893), is relatively sparse. On the other hand, there are several archaeological studies on this subject.

Here were developed malacological research on two shell-middens situated near Momuna village (Iguape, São Paulo State), similarly as the study of Bigarella (1949), done in the Paranaguá coastal plain (Paraná State, Brazil). During the identification of the mollusks species, stable carbon isotope ratios $\left({ }^{13} \mathrm{C} /{ }^{12} \mathrm{C}\right)$ and radiocarbon $\left({ }^{14} \mathrm{C}\right)$ ages were obtained from the shells, which provided important information on the paleoenvironmental changes occurred in the area.

This type of study is important for a better understanding of the near past paleoenvironmental changes on Earth, and is frequently useful to forecast near-future (approximately 100 years) fluctuations.

\section{THE STUDY SITE}

The shell-middens covered in this study are located near the Momuna village, approximately $17 \mathrm{~km}$ west from Iguape (São Paulo State), on Pleistocene wave-built terraces of the Cananeia Formation (Suguio and Martin, 1978a). The shell-middens are located at the right margin of the Ribeira de Iguape river (Figure 1) and are called in this paper Momuna 1 and Momuna 2.

The Momuna 1 shell-midden is located approximately $13 \mathrm{~km}$ from the Valo Grande channel and $3.7 \mathrm{~km}$ from the Momuna village, which is located at $24^{\circ} 42^{\prime} 29^{\prime \prime} \mathrm{S}$ latitude and $47^{\circ} 33^{\prime} 19^{\prime \prime} \mathrm{W}$ longitude. In the past, lot of shells were probably taken-out from this shell-midden due to commercial exploitation. Therefore, its original shape seems to have been destroyed, which was probably facilitated by its location at the side of the road to Momuna village (Figure 2). Presently the shell-midden is approximately $3 \mathrm{~m}$ high and $50 \mathrm{~m}$ long. This shellmidden has a coquinoid deposit, which is a distinguishing feature not very common in shell-middens, suggesting that it probably underwent post-depositional submergence, which could have propitiated partial dissolution of the shells, followed by their cementation.

The Momuna 2 shell-midden is located approximately $4.6 \mathrm{~km}$ from the Momuna village going toward the Jairé village, which is located at $24^{\circ} 39^{\prime} 40^{\prime \prime} \mathrm{S}$ latitude and $47^{\circ} 40^{\prime} 36^{\prime \prime} \mathrm{W}$ longitude. This shell-midden is located approximately $50 \mathrm{~m}$ from the right margin of the Ribeira de Iguape river, at the foot of a low crystalline hill, and there is an inhabited dwelling covering part of its area (Figure 3).

\section{REGIONAL SETTING}

The Cananeia-Iguape coastal plain is situated in the Província Costeira of Almeida (1964), integrating the Serra do Mar orographic setting, which is composed of Precambrian granitic and middle-to-high-grade metamorphic (gneisses, migmatites and granulites) rocks, diabase dikes associated with the Gondwana break-up during the Mesozoic (Gimenez Filho et al., 1987), and Cenozoic sediments.

The Cenozoic sediments occur in the Cananeia-Iguape coastal plain, which is predominantly composed of sandy Pleistocene sediments of the Cananeia Formation (Suguio 


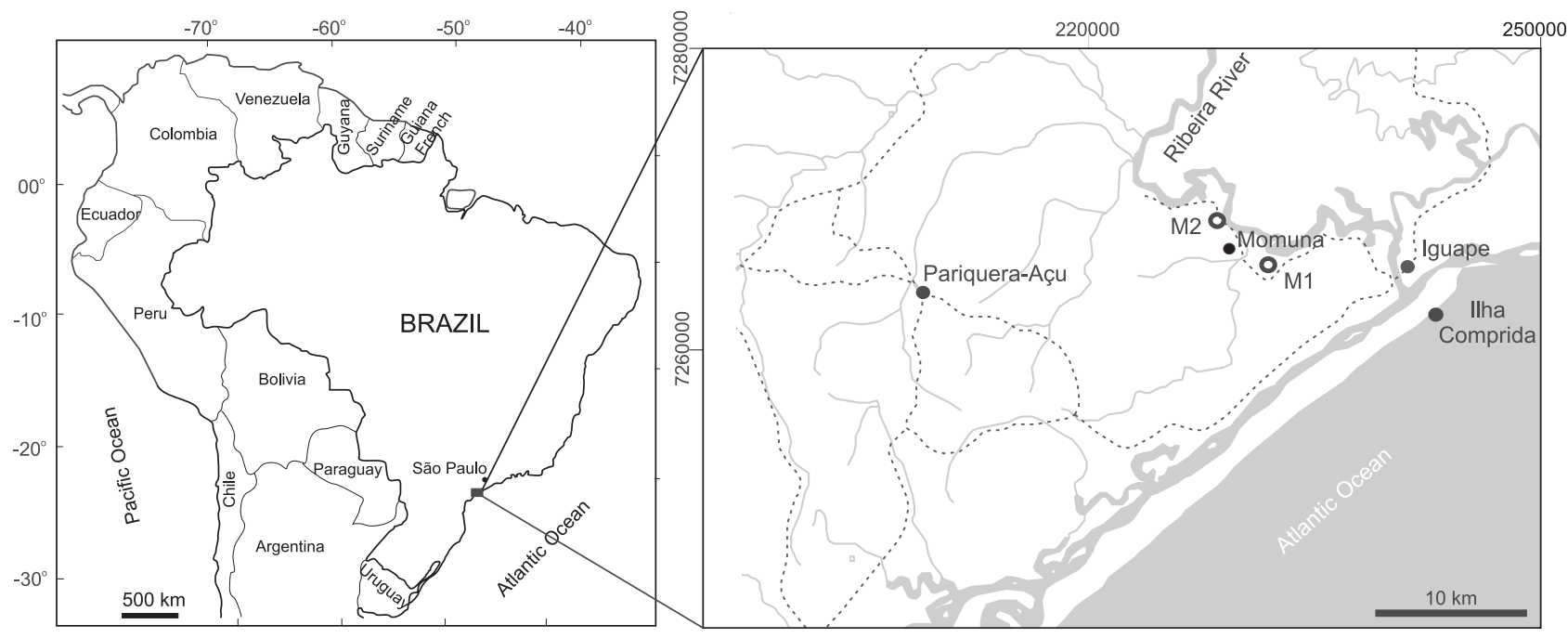

Figure 1. Geographic location map of the Momuna 1 (M1) and Momuna 2 (M2) shell-middens, near the Momuna village (Iguape, São Paulo State, Brazil).
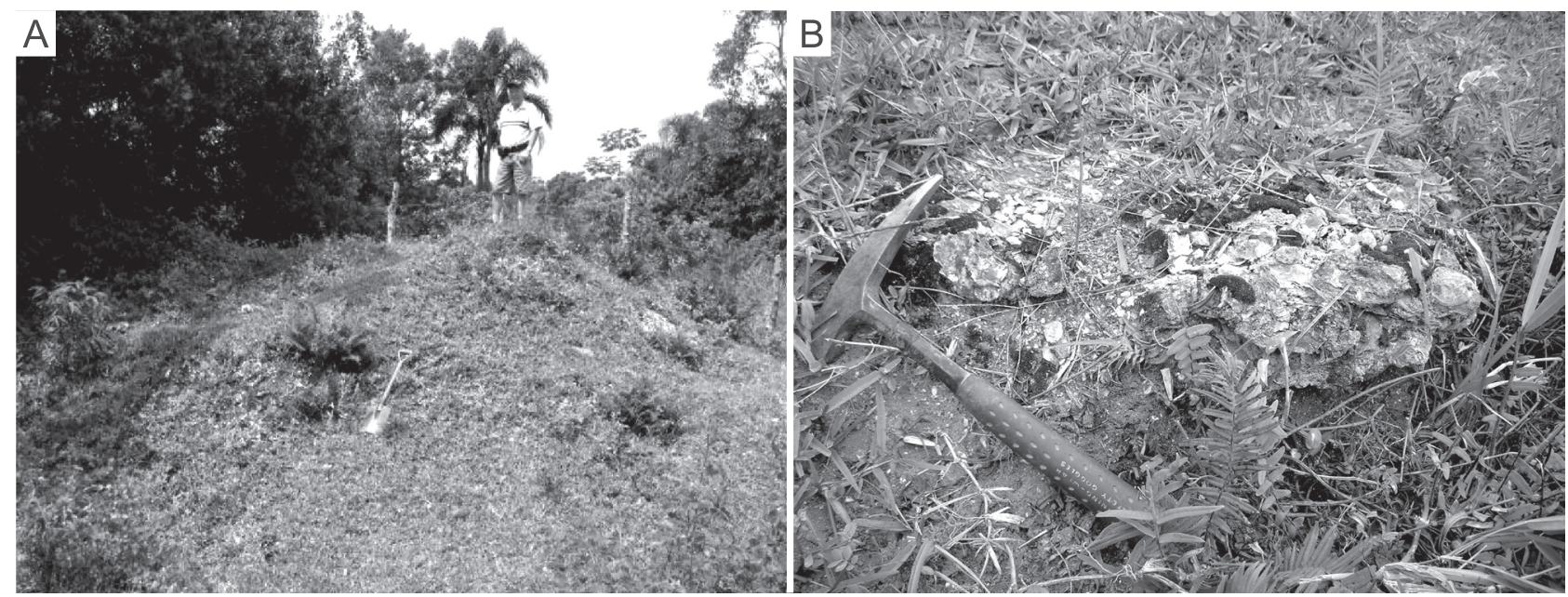

Figure 2. Present appearance of the Momuna 1 shell-midden covered by vegetation, which is particularly dense in the shell-midden. (A) General view of the shell-midden, and (B) Cemented oyster shells forming a true coquina.

and Petri, 1973) in the surface. The free spaces between the crystalline rocks and the Cananeia Formation sediments are occupied by the paleolagoon organic clayey sands, which are separated from the open-sea by 3 to $5 \mathrm{~km}$ wide strandline sands, attributed by Suguio and Martin (1994) to the Ilha Comprida Formation.

During the Cenozoic, several episodes of climate change and tectonic movements occurred, followed by relative sea-level oscillations (Suguio and Martin, 1978a). The Serra do Mar upstream erosion and the shoreline retreat until the present position propitiated an intense Neogene sedimentation in the Bacia de Santos (Souza and Souza, 2004) within the presently submerged basin. The oldest Cenozoic deposits occur only in the subsurface and are known as the Pariquera-Açu Formation (ServantVildary and Suguio, 1990), which was described during the Nuclebrás drilling process in the decade of 1980. These drilling data showed that there are more than $100 \mathrm{~m}$ of unlevellings near the present shoreline, which is suggestive of the occurrence of paleovalleys excavated 

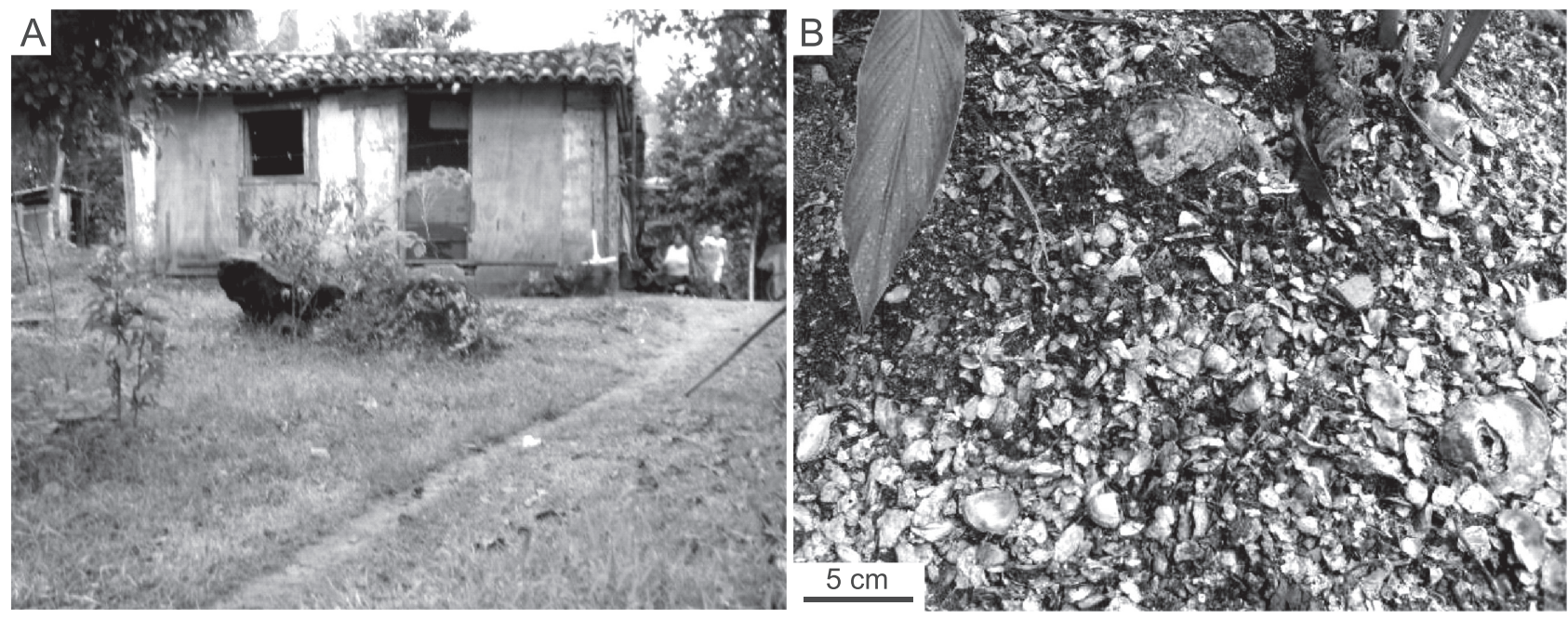

Figure 3. Present situation of the Momuna 2 shell-midden, covered by a house. (A) Inhabited rustic house and (B) shells with dominance of Anomalocardia brasiliana and very scarce Crassostrea sp.

in the Precambrian basement between the Mesozoic and Cenozoic eras. These paleovalleys were filled with the continental Neogene deposits of the Pariquera-Açu Formation, whose upper part was eroded afterwards.

On the other hand, the past climate changes played an important role in the coastal morphogenesis and sedimentogenesis of the area. The evolutionary history was recorded in several lowered coastal plains composed of shallow-marine, fluvial, lagoonal and colluvial deposits (Suguio and Martin, 1978b).

Quaternary relative sea-level higher than the present: four generations of marine terraces indicative of relative sea-level higher than the present one were described as barrier island-lagoon systems I to IV, from the highest and oldest to the lowest and newest, despite their absolute ages have not been measured by Villwock et al. (1986) and Tomazelli and Villwock (1996, 2000). Based on these records, at least the barrier island-lagoon deposits I and II, when correlated to the oxygen isotope curve of Imbrie et al. (1984; according to Tomazelli and Villwock, 2000), have been interpreted as older than 120 ky B.P. (Figure 4).

120 ky B.P. ancient sea-level: the oldest transgressive episode, which is represented in the study area by the barrier island-lagoon system II, was followed by the worldwide known highest sea-level event, which corresponds to the Sangamon (USA) and Eemian (Scandinavia) Upper Pleistocene stades (Bloom et al., 1974; Chappell, 1983), and is correlatable with the Rio Grande do Sul State barrier island-lagoonal system III (Villwock et al., 1986), probably assigned to the oxygen isotope substage $5 \mathrm{c}$. At that time, the relative sea-level was approximately $8 \pm 2 \mathrm{~m}$ above the present level in most of the Brazilian coastline (northeastern, eastern, southeastern and southern). This episode was called "Cananeia Transgression" by Suguio and Martin (1978a) in the São Paulo State and "Penultimate Transgression" by Bittencourt et al. (1979), whose study includes data collected from the state of Rio Grande do Sul (Tomazelli and Villwock, 2000) to the state of Rio Grande do Norte (Suguio, Barreto, Bezerra, 2001).

Holocene higher ancient sea-level: the last transgressive episode is known as Santos Transgression (Suguio and Martin, 1978a) in Brazil and Flandrian Transgression in the Netherlands. This episode started approximately 17.5 ky B.P. and, according to Villwock et al. (1986), is represented by the barrier island-lagoon system IV (Figure 4 ), and reached its culmination stage approximately 5 to 6 ky B.P.

Suguio and Martin (1978a) proposed an useful evolutionary model for the Jureia-Itatins Ecological Station represented by the following stages (Figure 5):

a. First stage: during the Cananeia Transgression maximum, the sea-level might have reached the foot of the Serra do Mar, forming the transitional littoral sands and clayey sands, which covered part of the continental deposits of the Pariquera-Açu Formation;

b. Second stage: This stage is characterized by regressive beach-ridge deposits, which covered the upper part of the Cananeia Formation; 


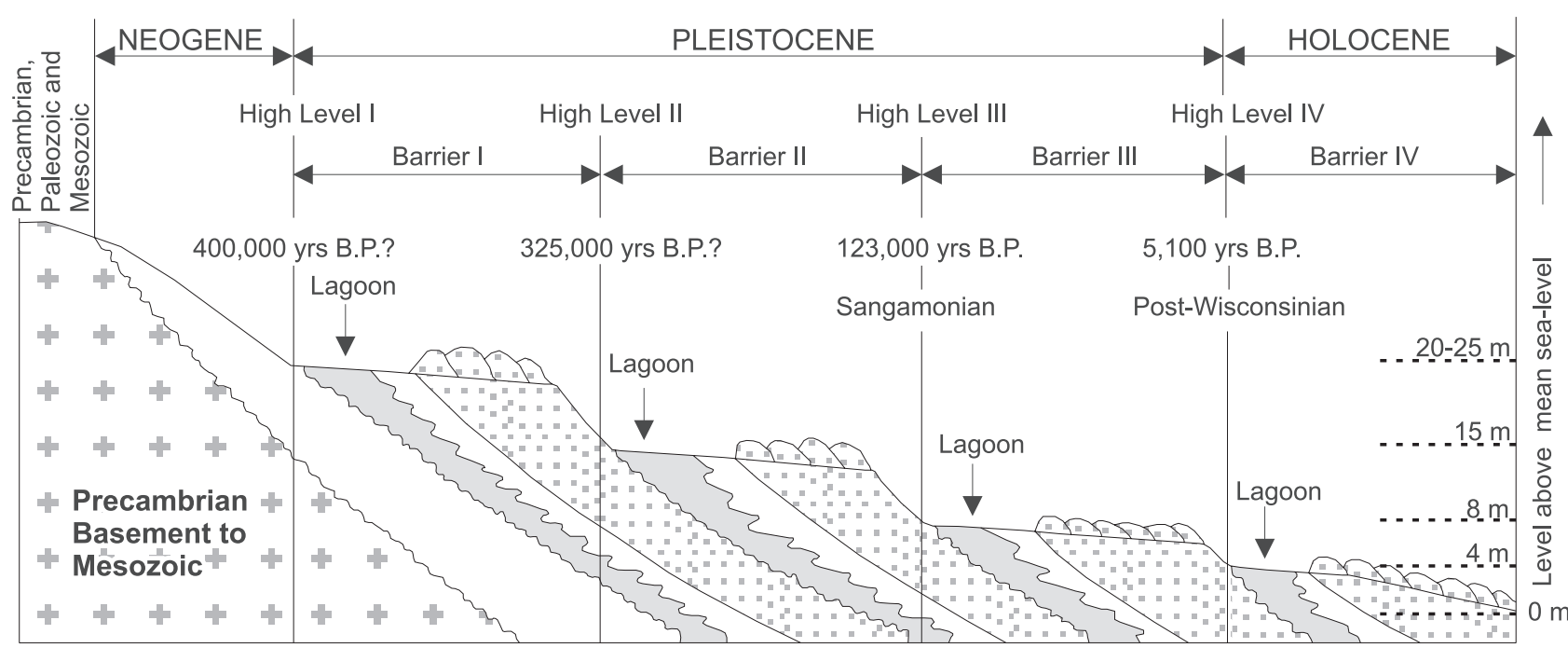

$\sum$ Transgressive sequence

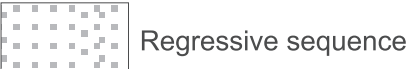

Figure 4. Four barrier-island/lagoon systems recorded in the Rio Grande do Sul coastal plain indicate four relative sea-level stages above the present sea-level during the Quaternary (Villwock et al., 1986, Tomazelli and Villwock, 1996).

$1^{\text {st }}$ stage - Maximum Transgression Cananeia

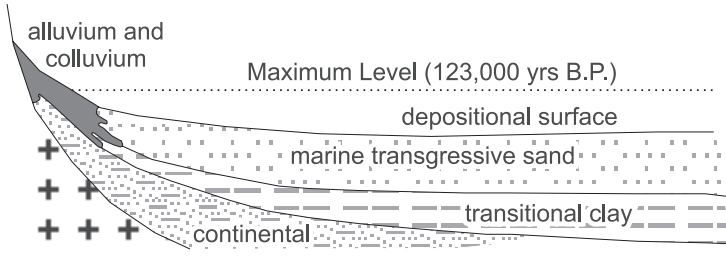

$2^{\text {nd }}$ stage - Regression and deposition of beach ridges

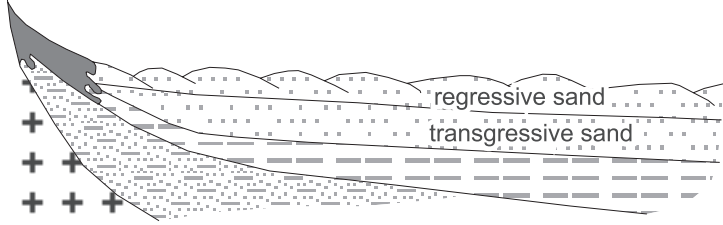

$3^{\text {rd }}$ stage - Partial erosion of the marine deposits

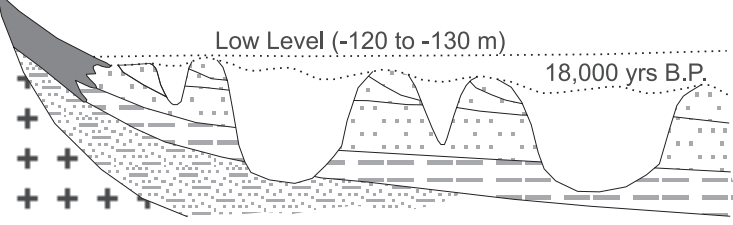

$4^{\text {th }}$ stage - Maximum Transgression Santos (Post-glacial)

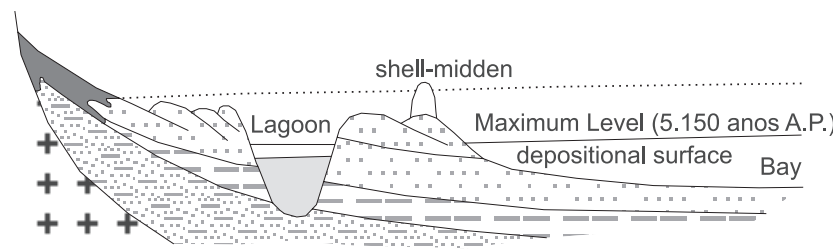

$5^{\text {th }}$ stage - Formation of a barrier island

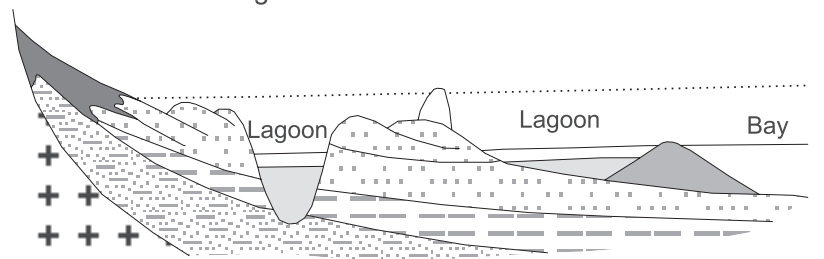

$6^{\text {th }}$ stage - Regression toward the current level

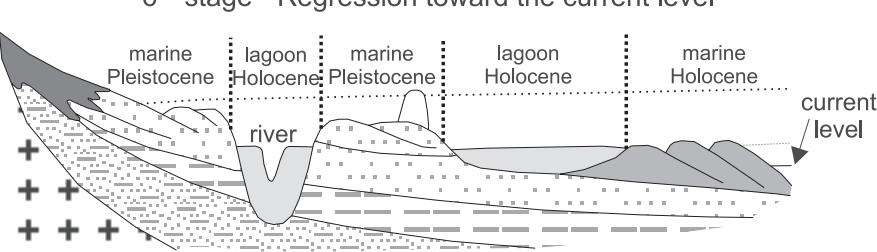

Figure 5. Late Quaternary geological evolutionary stages of the Cananeia-lguape-llha Comprida coastal plain (Suguio and Martin, 1978a). 
c. Third stage: Approximately 17.5 ky B.P, the relative sea-level dropped to 120 to $130 \mathrm{~m}$ below the present level, and the fluvial drainage network of the coastal plain eroded partially the Cananeia formation and the Pariquera-Açu formation;

d. Fourth stage: The eroded portions of the Cananeia Formation were encroached by the Santos Transgression, which, during its culmination stage, formed extensive ancient estuarine environments favorable to human occupation, which is testified by the shell-middens found in the area;

e. Fifth stage: This stage took place after the Holocene culmination, when the partially eroded Pleistocene Cananeia Formation was covered by reworked sediments, which originated the Holocene Ilha Comprida Formation.

f. Sixth stage: The ancient relative sea-level reached a level similar to the present one, and the Holocene regressive beach-ridge prograded at this time. Meanwhile the ancient estuaries were gradually filled with sediments, and transformed from salt-water to brackish-water and finally freshwater environments.

\section{MATERIAL AND METHODS}

\section{Collection of samples}

The samples of the mollusks shells were collected from two distinct parts, chosen by chance, of each shellmidden. They were obtained through excavation, using a shovel and a geological hammer, and placed inside a plastic bag and then properly labeled (Figure 6). Voucher samples are added to the malacological collection of the Zoology Museum of the University of São Paulo and the UnG Geosciences Laboratory.

\section{Malacological analyses}

In the laboratory, the collected samples were washed with running water, using brushes to remove the earthy and organic materials. Based on some previously published papers, we made possible interpretations about the data obtained in this study.

\section{Chronology and isotopic analysis}

The ages and the carbon isotopic composition analysis $\left({ }^{13} \mathrm{C} /{ }^{12} \mathrm{C}\right)$ of three shell samples collected from the Momuna 1 and Momuna 2 shell-middens were obtained by Beta Analytic Inc. (USA). The ages were determined using extended counting and accelerator mass spectrometry (AMS) radiocarbon analyses. The samples were pretreated with acid etching to eliminate secondary carbon components. The material was then crushed, dispersed and repeatedly subjected to $\mathrm{HCl}$ etching to leach secondary carbonate components. The radiocarbon age and the stable carbon isotope ratios obtained by Martin et al. (1979) for one shell sample from the Momuna 1 shellmidden were also used in this study.

This study uses conventional time-stratigraphic nomenclature, and radiocarbon $\left({ }^{14} \mathrm{C}\right)$ ages are given as years before present (yr BP), fixed at AD 1950. These ages were converted to calibrated ${ }^{14} \mathrm{C}$ ages (cal. yr BP)
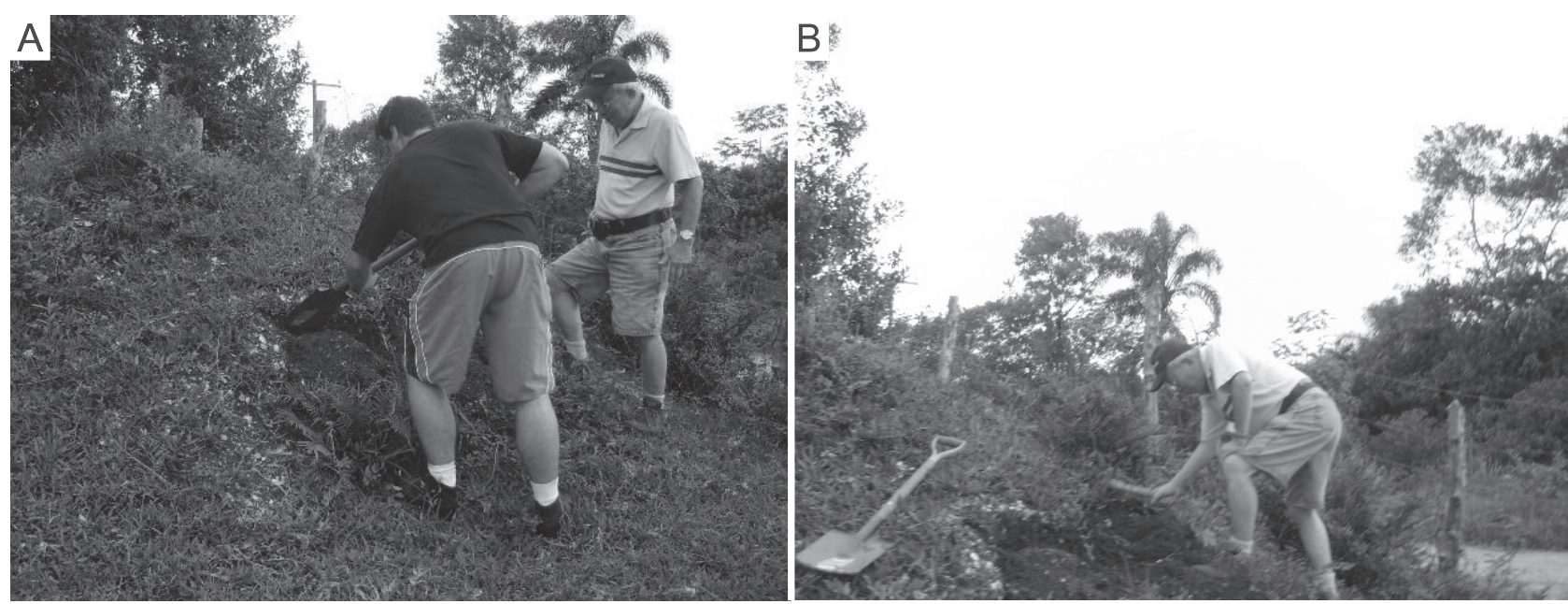

Figure 6. Collecting shells in the Momuna 1 shell-midden: (A) with a shovel; and (B) with a geological hammer. 
by Beta Analytic Inc. (Stuiver et al., 1998 and Talma and Vogel, 1993), assuming two-sigma error on radiocarbon measurements with error multiplier of 1.0. The radiocarbon ages were calibrated with the Southern Hemisphere Calibration using SHCAL04 (McCormac et al., 2004).

Carbon isotope results were previously reported in per mil relative to VPDB (Vienna Peedee Belemnite) by assigning a value of +1.95 per mil to NBS $19 \mathrm{CaCO}_{3}$ (Coplen, 1994), which is used as carbon isotopic compositions of internationally distributed isotopic reference materials (Coplen et al., 2006).

\section{RESULTS AND DISCUSSION}

\section{Qualitative analysis of the shells}

The good preservation of the collected shells allowed an accurate classification of the species (Figure 7):

\section{Crassostrea rhizophorae and Crassostrea brasiliana}

The distinction between both species is difficult and is mainly based on the plasticity of the shells. Revision of these taxa is in progress and the identification is at the generic level in this study. On the other hand, both species live in similar environmental conditions, which is brackish-water with high carbon availability.

\section{Lucina pectinata}

This mollusk lives buried in muddy bottom of mangrove swamps in calm water estuaries. The specimens examined in this study showed irregularities in the shell growth lines, which suggests that the current became faster on some occasions during the mollusk lifetime. A barnacle incrustation (Balanus sp.) was also found in the shell of this species.

\section{Mytella guyanensis}

The presence of this mollusk in the shell-middens studied here suggests that it was collected during ebb tides, since it lives buried approximately $20 \mathrm{~cm}$ in muddy sand. It has therefore a behavior similar to that of Lucina pectinata.

Only three broken specimens attributable to this mollusk were collected from the studied shell-middens.

\section{Anomalocardia brasiliana}

This is an eurythermal and euryhaline species, which shows great resistance to oxygen deficiency. It lives buried in muddy bottoms in intertidal zones of sheltered shallow brackish-water environments. The presence of these mollusk shells is suggestive of estuarine waters in the vicinity at a time when RSL was above the present level.

\section{Quantitative analysis of the shells}

The counting of the shell specimens according to different taxa enabled the estimation of the relative frequency of the mollusks species found in the Momuna 1 (Table 1) and Momuna 2 (Table 2) shell-middens.

Table 1. Malacofauna composition of the Momuna 1 shell-midden (Iguape, SP).

\begin{tabular}{ccc}
\hline \multirow{2}{*}{ Taxa } & \multicolumn{2}{c}{ Partial frequency } \\
& Numerical & $\%$ \\
\hline Crassostrea brasiliana & 289 & 92.33 \\
Lucina pectinata & 21 & 6.71 \\
Mytella guyanensis & 3 & 0.96 \\
Total frequency & 313 & 100.00 \\
\hline
\end{tabular}

Table 2. Malacofauna composition of the Momuna 2 shell-midden (Iguape, SP).

\begin{tabular}{ccc}
\hline \multirow{2}{*}{ Taxa } & \multicolumn{2}{c}{ Partial frequency } \\
& Numerical & $\%$ \\
\hline Anomalocardia brasiliana & 213 & 66.36 \\
Crassostrea brasiliana & 87 & 27.10 \\
Crassostrea rizophorae & 21 & 6.54 \\
Total frequency & 321 & 100.00 \\
\hline
\end{tabular}

From 313 shells samples collected from the Momuna 1 shell-midden, most of them were unbroken but some were shell fragments; 289 specimens (92.33\%) were represented by Crassostrea brasiliana, followed by Lucina pectinata with 21 specimens (6.71\%), and finally by Mytella guyanensis with 3 specimens $(0.96 \%)$.

The samples collected from the Momuna 2 shellmidden were represented by 321 specimens: 213 (66.36 $\%)$ specimens were represented by Anomalocardia brasiliana, 87 (27.10\%) by C. brasiliana and 21 (6.54\%) by $C$. rhizophorae.

The differences between the species of mollusks found in the Momuna 1 and Momuna 2 shell-middens can be attributed to the different availabilities of these 

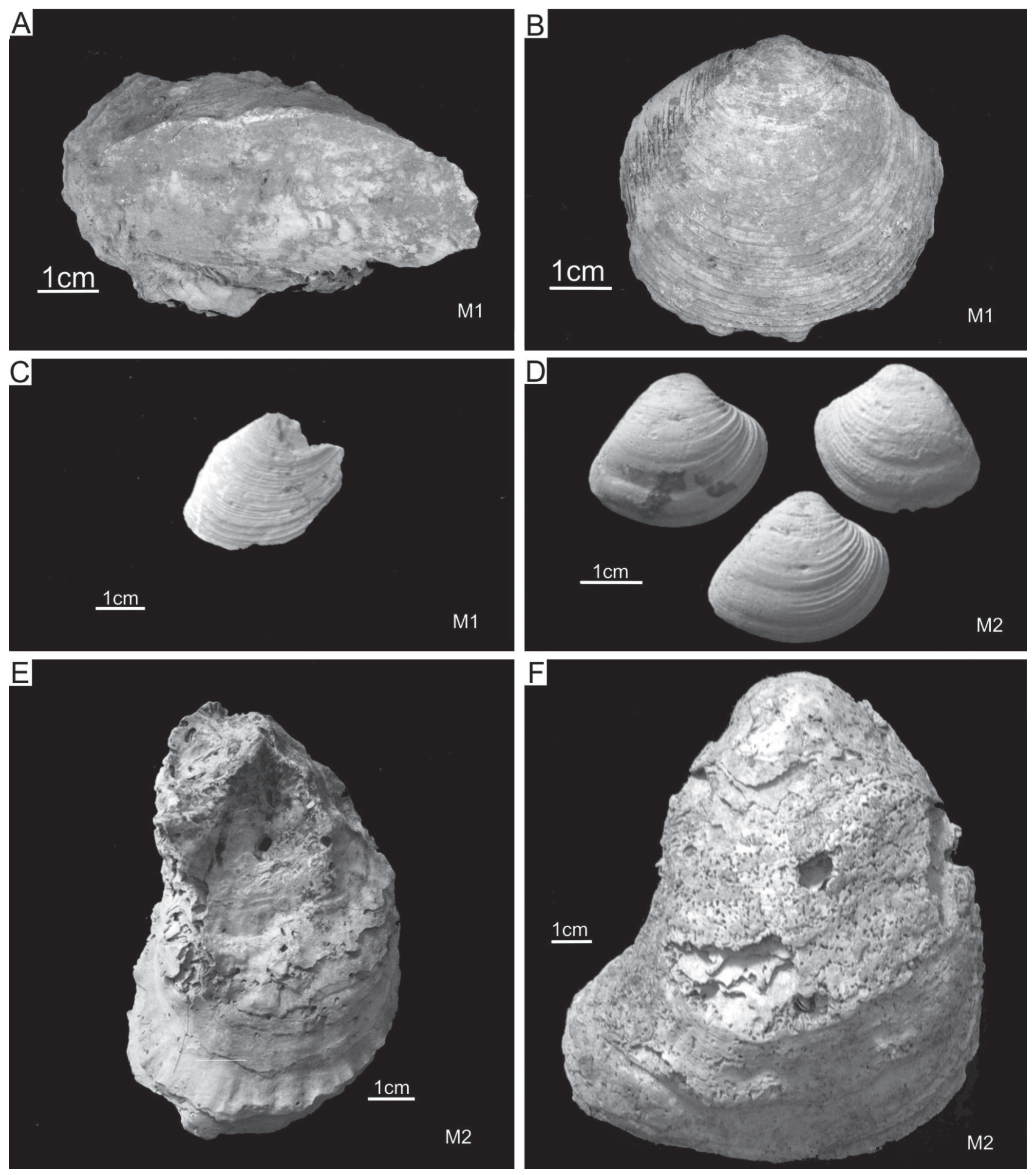

Figure 7. General appearance of the shells from the shell-middens: (A; E) Crassostrea brasiliana, (B) Lucina pectinata, (C) Mytella guyanensis, (D) Anomalocardia brasiliana and (F) Crassostrea rhizophorae. 
species in the collecting sites and in the neighborhood. Therefore, Crassostrea brasiliana was more abundant in the vicinities of the Momuna 1 shell-midden, whereas Anomalocardia brasiliana was more common near the Momuna 2 shell-midden. On the other hand, we can assume that the people who lived close to the shellmidden area preferred one species over the other, especially if they were used as food.

\section{Isotope ratios of the shells}

The ages of the shells were obtained using radiocarbon $\left({ }^{14} \mathrm{C}\right)$ dating, which measures the residual radioactivity (knowing how much ${ }^{14} \mathrm{C}$ is left in a sample, the age of the organism when it died can be known). On the other hand, the isotope fractionation leads to different ${ }^{13} \mathrm{C} /{ }^{12} \mathrm{C}$ stable isotope ratios, in such a way that more positive (or less negative) values indicate increasing oceanicity (greater marine influence), whereas more negative (or less positive) values indicate increasing continentality (greater continental influence) (Martin, Suguio, Flexor, 1984).

\section{Radiocarbon ages and isotopic values}

The radiocarbon ages and stable carbon isotope ratios below were obtained for the mollusk shells collected from the studied shell-middens (Table 3 ).

The RSL (Relative Sea-Level) fluctuation curve outlined by Suguio et al. (1985) for the last 7 ky B.P. was used to show the possible significance of the above mentioned ages in terms of the sea-level history in the Iguape (São Paulo State) coastal plain (Figure 8).

Certainly, the shell-middens covered in this study were formed during several hundred to several thousand years.

Table 3. Radiocarbon ages for the shells collected from the Momuna 1 and Momuna 2 shells-middens. The age intervals are given as calendar years B.P., assuming a one-sigma error on the radiocarbon measurements. Analyses were performed by Beta Analytic. * Calibrated ages are calculated using SHCALO4 (McCormac et al., 2004). ** Calibrated ages are calculated by Stuiver et al. (1998) and Talma and Vogel (1993), assuming two-sigma error on radiocarbon measurements with error multiplier of 1.0; cal. = calibration was performed by Beta Analytic. ${ }^{* * *}$ Martin et al. (1979) - Bah. = Applied Nuclear Physics Laboratory - Federal University of Bahia (UFBA), Brazil.

\begin{tabular}{cccccc}
\hline Sample & $\begin{array}{c}\text { Lab. } \\
\text { number }\end{array}$ & $\delta^{13} \mathrm{C}_{\mathrm{PDB}}$ & ${ }^{14} \mathrm{C}$ Age & $\begin{array}{c}\text { Calendar age } \\
\text { (cal. yr B.P.) }^{*}\end{array}$ & $\begin{array}{c}\text { Calendar age range } \\
{\text { (cal. yr B.P. } \pm 2 \sigma)^{* *}}^{*}\end{array}$ \\
\hline Momuna 1 & Beta -238841 & -7.4 & $5.360 \pm 70$ & 6.020 & 5.890 to 5.580 \\
Momuna $^{* * *}$ & Ba -308 & -5.39 & $4.790 \pm 150$ & 5.555 & - \\
Momuna 2A & Beta -244543 & -3.8 & $5.130 \pm 40$ & 5.815 & 5.580 to 5.430 \\
Momuna 2B & Beta - 244544 & -4.1 & $4.990 \pm 50$ & 5.595 & 5.460 to 5.250 \\
\hline
\end{tabular}

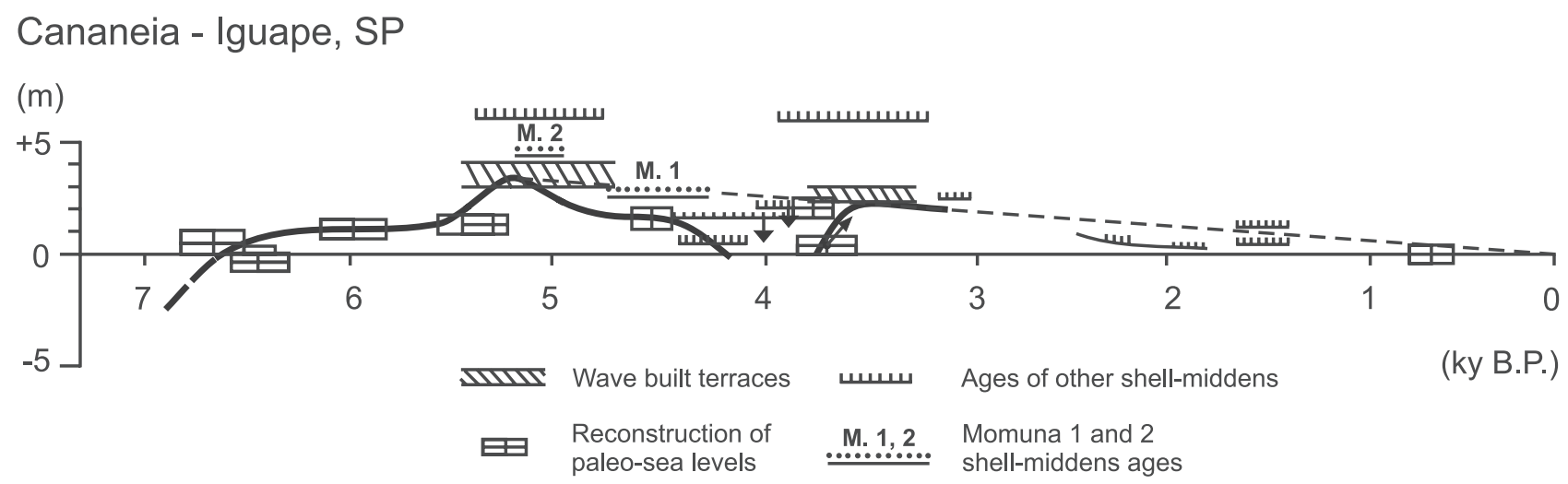

Figure 8. RSL (Relative Sea-Level) change curve for the Cananéia-lguape coastal plain during the last 7 ky B.P. (Suguio et al., 1985), showing the positions of the ages obtained in this study from the Momuna 1 and 2 shells-middens. 
Therefore, it is possible that other samples collected from different parts of these shell-middens might yield different ages from the above mentioned ones. On the other hand, these ages could be useful as ancient RSL indicator, if the following hypotheses proposed by Suguio, Martin and Flexor (1992) are considered correct:

1. at the beginning of the shell-midden formation, the local RSL was below its substrate and, therefore, it began to be formed on an emerging surface; and

2. the shell-middens located far from the present shoreline, some kilometers inland, are probably related to a paleolagoon expansion phase that occurred between 5 and 6 ky B.P, when the RSL was above the present level.

\section{CONCLUSIONS}

The ages obtained for both shell-middens are very similar and consistent because they are close to the culmination stage of the hypsithermal age (Suguio, 2001). The Holocene maximum of the Santos Transgression occurred at this time and the RSL in the studied area was approximately 4 to $5 \mathrm{~m}$ above the present level (Suguio and Martin, 1978a).

However, their $\delta^{13} \mathrm{C}_{(\mathrm{PDB})}$ values are incongruous, since the Momuna 1 data showed more negative (or less positive) values, and the Momuna 2 data showed more positive (or less negative) values. If these results are correct, they indicate that the Momuna 1, which is located oceanward, has a higher continentality, whereas the Momuna 2, which is located landward, has a higher oceanicity, which seems to be a contradiction. Additional studies focusing on all shell-middens of the Cananeia-Iguape coastal plain are necessary to clarify this matter.

\section{ACKNOWLEDGEMENS}

The authors are grateful to the Research Support Foundation of the State of São Paulo (FAPESP) for granting the Project (Process 2006/04467-7) to Kenitiro Suguio. They are also grateful to the National Brazilian Research Council (CNPq) for awarding a research productivity fellowship to Kenitiro Suguio.

\section{REFERENCES}

ALMEIDA, F. F. M. Fundamento geológico do relevo paulista. Boletim do Instituto Geográfico e Geológico, n. 41, p. 167-263, 1964.

BIGARELLA, J. J. Nota prévia sobre a composição dos sambaquis do Paraná e Santa Catarina. Boletim de Arquivos de Biologia e Tecnologia, n. 4, p. 95-106, 1949.
BITTENCOURT, A. C. S. P.; MARTIN, L.; VILASBOAS, G. S.; FLEXOR, J. M. The marine formations of the coast of the State of Bahia, Brazil. In: INTERNATIONAL SYMPOSIUM ON COASTAL EVOLUTION IN THE QUATERNARY, 1978, São Paulo. Proceedings... São Paulo: IGc, 1979. p. 232-253.

BLOOM, A. L.; BROECKER. W. S.; CHAPELL, J. M. A.; MATTHEWS, R. K.; MESOLELLA, K. J. Quaternary sea-level fluctuation: new ${ }^{230} \mathrm{Th} /{ }^{234} \mathrm{U}$ dates from New Guinea. Quaternary Research, v. 4, p. 185-205, 1974.

CHAPPELL, J. M. A. A revised sea-level records of the last 300,000 years from Papaua - New Guinea. Search, v. 14, p. 99-104, 1983.

COPLEN, T. B. Reporting of Stable Hydrogen, Carbon, and Oxygen Isotopic Abundances. Pure and Applied Chemistry, v. 66, p. 273-276, 1994.

COPLEN, T.B.; BRAND, W. A.; GEHRE, M.; GRÖNING, M.; MEIJER, H. J.; TOMAN, B.; VERKOUTEREN, R. M. New guidelines for $\delta^{13} \mathrm{C}$ measurements. Analytical Chemistry, v. 78, p. 2439-2441, 2006.

FLEXOR, J. M.; MARTIN, L.; SUGUIO, K. Utilisation du rapport isotopique ${ }^{13} \mathrm{C} /{ }^{12} \mathrm{C}$ comme indicateur d'oscillations lagunaires. In: INTERNATIONAL SYMPOSIUM ON COASTAL EVOLUTION IN THE QUATERNARY, 1978, São Paulo. Proceedings... São Paulo: IGc, 1979. p. 356-375.

GIMENEZ FILHO, A.; DANTAS A. S. L.; NAGATA, N.; ALBUQUERQUE FILHO, J. L.; FERNANDES, L. A.; TEIXEIRA, A. L. Geologia da Folha Miracatu, Sul-Sudeste do Estado de São Paulo. In: SIMPÓSIO REGIONAL DE GEOLOGIA, 6., 1987, Rio Claro. Atas... Rio Claro, SBG/NSP, v. 2, 1987. p. 225-241.

IMBRIE, J.; HAYS, J. D.; MARTINSON, D. G.; MCINTYRE, A.; MIX, A. C.; MORLEY, J. J.; PISIAS, N. G.; PRELL, W. L.; SHACKLETON, N. J. The orbital theory of Pleistocene climate: support from a revised chronology of the marine $\delta^{18} \mathrm{O}$ record. In: BERGER, A.L.; IMBRIE, J.; HAYS, J.; KUKLA, G.; SALTZMAN, B. (Ed). Milankovitch and Climate. Boston: Reidel, Parte 1, 1984. p. 269-305.

LÖFGREN, A. Os Sambaquis de São Paulo. Boletim da Comissão Geográfica e Geológica do Estado de São Paulo, n. 9, p. 1-54, 1893.

MARTIN, L.; FLEXOR, J. M.; VILAS-BOAS, G. S.; BITTENCOURT, A .C. S. P. Courbe de variations du niveau 
relative de la mer au coust de 7000 dernieres années sur um secteur homogene du littoral brésilien (nord de Salvador, Brésil). In: INTERNATIONAL SYMPOSIUM ON COASTAL EVOLUTION IN THE QUATERNARY, 1978, São Paulo. Proceedings... São Paulo: IGc, 1979, p. 356-375.

MARTIN, L.; SUGUIO, K. ; FLEXOR, J. M. Informações adicionais fornecidas pelos sambaquis na reconstrução de paleolinhas de praia quaternária: Exemplos da costa do Brasil. Separata da Revista de Pré-História USP, v. 6, p. 128-147, 1984.

MCCORMAC, F. G.; HOGG, A. G.; BLACKWELL, P. G.; BUCK, C. E.; HIGHAM, T. F. G.; REIMER, P. J. SHCal04 Southern Hemisphere Calibration 0 - 1000 cal BP. Radiocarbon, v. 46, n. 3, p. 1087-1092, 2004.

NEVES, W. A.; OKUMURA, M. M. M. Afinidades biológicas de grupos pré-históricos do rio Ribeira de Iguape (SP). Revista de Antropologia, v. 48, n. 2, p. $525-558,2005$.

SERVANT-VILDARY, S.; SUGUIO, K. Marine Diatom study and stratigraphy of Cenozoic sediments in the coastal plain between Morro da Jureia and Barra do Una, State of São Paulo, Brazil. Quaternary of South America and Antarctic Peninsula, v. 6, p. 267-296, 1990.

SOUZA, C. R. DE G.; SOUZA, A. P. Geologia e Geomorfologia da área da Estação Ecológica JureiaItatins. In: MARQUES, O. A. V.; DULEBA, W. (Ed.). Estação Ecológica Jureia-Itatins - Ambiente Físico, Flora e Fauna. Ribeirão Preto: Holos, 2004. p. 16-33.

STUIVER, M., REIMER, P. J.; BARD, E.; BECK, J.W.; BURR, G. S.; HUGHEN, K. A.; KROMER, B.; MCCORMAC, G.; VAN DER PLICHT, J.; SPURK, M. INTCAL98 Radiocarbon Age Calibration, 24000-0 cal BP. Radiocarbon, v. 40, n. 3, p. 1041-1083, 1998.

SUGUIO, K. Influence of the "Hypsithermal Age" and "Neoglaciation" climatic conditions on the Brazilian coast. Pesquisas Geociências, v. 28, n. 2, p. 213-222, 2001.

SUGUIO, K.; BARRETO, A. M. F.; BEZERRA, F. H. R. Formações Barra de Tabatinga e Touros: evidências de paleoníveis do mar pleistocênicos da costa norteriograndense. Pesquisa Geociências, v. 28, p. 5-12, 2001.

SUGUIO, K.; MARTIN, L. Quaternary marine formations of the States of São Paulo and southern Rio de Janeiro. In: INTERNATIONAL SYMPOSIUM ON COASTAL
EVOLUTION IN THE QUATERNARY, 1978, São Paulo. Special Publication... São Paulo: IGc, 1978a, n 1, p. 1-55.

SUGUIO, K.; MARTIN, L. Mapas geológicos da Planície costeira do Estado de São Paulo e sul do Rio de Janeiro.São Paulo: DAEE/ Secretaria de Obras e do Meio Ambiente, Governo do Estado de São Paulo. 1978b. 1 mapa, color., $100 \mathrm{~cm}$ x $90 \mathrm{~cm}$. Escala 1:100.000.

SUGUIO, K.; MARTIN, L.; BITTENCOURT, A. C. S. P.; DOMINGUEZ, J. M. L.; FLEXOR, J. M.; AZEVEDO, A .E. G. Flutuações do nível relativo do mar durante o quaternário superior ao longo do litoral brasileiro e suas implicações na sedimentação costeira. Revista Brasileira de Geociências, v. 15, p. 273-286, 1985.

SUGUIO, K.; MARTIN, L.; FLEXOR, J. M. Paleoshorelines and sambaquis of Brazil. In: JOHNSON, L. L.; STRIGHT, M. Paleoshorelines and prehistory: an investigation of method. London: CRC Boca Raton, 1992. p. 83-99.

SUGUIO, K.; MARTIN, L. Geologia do Quaternário. In: FALCONI, F. F.; NIGRO Jr, A. (Ed.). Solos do litoral de São Paulo. Santos: ABMS/ASSECOB, 1994. p. 69-97.

SUGUIO, K.; PETRI, S. Statigraphy of the IguapeCananeia lagoonal region sedimentary deposits, São Paulo State, Brazil. Part I: field observations and grains size analysis. Boletim do Instituto de Geociências da USP, v. 4, p. 1-20, 1973.

TALMA, A. S.; VOGEL, J. C. A simplified approach to calibrating ${ }^{14} \mathrm{C}$ dates. Radiocarbon, v. $35, \mathrm{n} .2$, p. 317-322, 1993.

TOMAZELLI, L. J.; VILLWOCK, J. A. Quaternary geological evolution of Rio Grande do Sul coastal plain, southern Brazil. Anais da Academia Brasileira de Ciências, v. 68, p. 373-382, 1996.

TOMAZELLI, L. J.; VILLWOCK, J. A. O Cenozóico no Rio Grande do Sul: geologia da planície costeira. In: HOLZ, M.; De ROS, L. F. (Ed.). Geologia do Rio Grande do Sul. Porto Alegre: CIGO/UFRGS, 2000. p. 375-406.

VILLWOCK, J. A.; TOMAZELLI, L. J.; LOSS, E. L.; DEHNHARDT, B. A. Geology of the Rio Grande do Sul Coastal Province. Quaternary of South America and Antarctic Peninsula, v. 4, p. 79-97, 1986. 
